University of Nebraska - Lincoln

DigitalCommons@University of Nebraska - Lincoln

Faculty Publications, College of Dentistry

Dentistry, College of

$9-1963$

\title{
The Development in vitro and in vivo of Fusion of the Palatal Processes of Rat Embryos
}

Thomas Moriarty

University of Nebraska - Lincoln

Sam Weinstein

University of Nebraska - Lincoln

R. D. Gibson

University of Nebraska - Lincoln

Follow this and additional works at: https://digitalcommons.unl.edu/dentistryfacpub

Part of the Other Medicine and Health Sciences Commons

Moriarty, Thomas; Weinstein, Sam; and Gibson, R. D., "The Development in vitro and in vivo of Fusion of the Palatal Processes of Rat Embryos" (1963). Faculty Publications, College of Dentistry. 5.

https://digitalcommons.unl.edu/dentistryfacpub/5

This Article is brought to you for free and open access by the Dentistry, College of at DigitalCommons@University of Nebraska - Lincoln. It has been accepted for inclusion in Faculty Publications, College of Dentistry by an authorized administrator of DigitalCommons@University of Nebraska - Lincoln. 


\title{
The Development in vitro and in vivo of Fusion of the Palatal Processes of Rat Embryos
}

\author{
by THOMAS M. MORIARTY ${ }^{1}$, SAM WEINSTEI N ${ }^{1}$ and R. D. G I B S O N ${ }^{2}$ \\ From the Departments of Graduate Orthodontics and Pharmacology, \\ University of Nebraska
}

WITH FOUR PLATES

\section{INTRODUCTION}

THE congenital anomaly of cleft palate can now be reproduced by a variety of teratogenetic agents in a number of laboratory animals (Kalter \& Warkany, 1959). Through the use of the induced cleft palate numerous studies have been directed toward detecting the developmental mishaps which create this defect. The work of Fraser et al. (1957) suggested that various positional factors of the developing palatal and facial structures may be the underlying cause for failure of palatal closure in mouse embryos. Walker \& Fraser (1956) observed elastic fibers among the palatal processes of mouse embryos which they suggested might impart a 'shelf force' necessary for proper closure and fusion. However, Walker (1961) has since reported that there is a mucopolysaccharide in the ground substance of the palatal mesenchyme rather than an elastic fiber network. Asling et al. (1960) noted a growth spurt of the developing mandible during the critical time of palatal process closure. Along with morphological positional effects the teratogenetic agents may affect the phase of direct cellular fusion of the two palatal processes. Different teratogens may even affect different developmental sites and still create the cleft defect. Even with the various morphological studies completed upon normal and cleft embryos the exact mechanism(s) causing the cleft palate defect remain unknown.

Often in vitro studies have solved problems which morphological studies were unable to answer. Organ culture techniques have been developed which allow direct observations of developmental changes, the effects of isolation, operations and varying physiological conditions upon developing tissues (Fell, 1940). Similarly transplantation experiments employing the transparent chamber techniques have been employed to study embryonic development (Sabet et al.,

${ }^{1}$ Authors' address: Department of Graduate Orthodontics, College of Dentistry, University of Nebraska, Lincoln, Nebraska, U.S.A.

${ }_{2}^{2}$ Author's address: Department of Pharmacology, College of Pharmacy, University of Nebraska, Lincoln, Nebraska, U.S.A. 
THOMAS M. MORIARTY, SAM WEINSTEIN AND R. D. GIBSON

1961). Development of isolated embryonic palatal processes through the phase of closure and fusion, as an organ culture or as a transplant, would allow direct observation of the mode of process contact and fusion and discrimination between tissue positional factors and tissue fusion ability in both normal and teratogenetic palatal tissues.

The purpose of this investigation was to determine the effectiveness of using in vitro and in vivo techniques in obtaining closure and fusion of isolated embryonic palatal processes of normal rat embryos; and to compare the morphology and histology of these tissues with the palatal structures of intact embryos.

\section{MATERIAL AND METHODS \\ Experimental animals}

All the embryonic palates used in the in vitro and in vivo experiments were obtained from embryos of the Sprague-Dawley strain of rats. Adult mice of the $\mathrm{C} 3 \mathrm{H} / \mathrm{Jax}$ strain were used as hosts for the heterograft experiments. The homograft experiments employed Holtzman rats as hosts.

The animals were housed in temperature controlled $\left(24 \pm 2^{\circ} \mathrm{C}\right.$.) animal quarters. Purina Laboratory Chow Checkers and water were available at all times.

\section{Embryo age determination}

An embryo's chronological age was recorded as the number of days and hours following conception assuming that this took place at midnight. With this measure, the age of all embryos used was 15 days plus 14 to $21 \mathrm{hr}$. (Plate 1, Fig. A).

\section{Operating procedures}

Sterile procedures were employed for all operations. The pregnant female rats were killed either by cervical decapitation or by $\mathrm{CO}_{2}$ asphyxiation. After

\section{Plate 1}

The operating procedure upon the embryo

FIG. A. Lateral view of the embryo.

FiG. B. Head resected along the transverse plane.

FIG. C. Mandible resected by an excision along the transverse plane.

Fig. D. Maxillary vault and associated structures removed by an excision along the transverse plane (inferior aspect).

FIG. E. Oral view of the maxillary vault and associated structures. Note the tongue is still in place between the lateral palatine processes. The tissue distal to the lateral palatine processes has been severed.

FIG. F. Oral view of final tissue section used in the experiments. The tongue has been withdrawn from between the lateral palatine processes. 

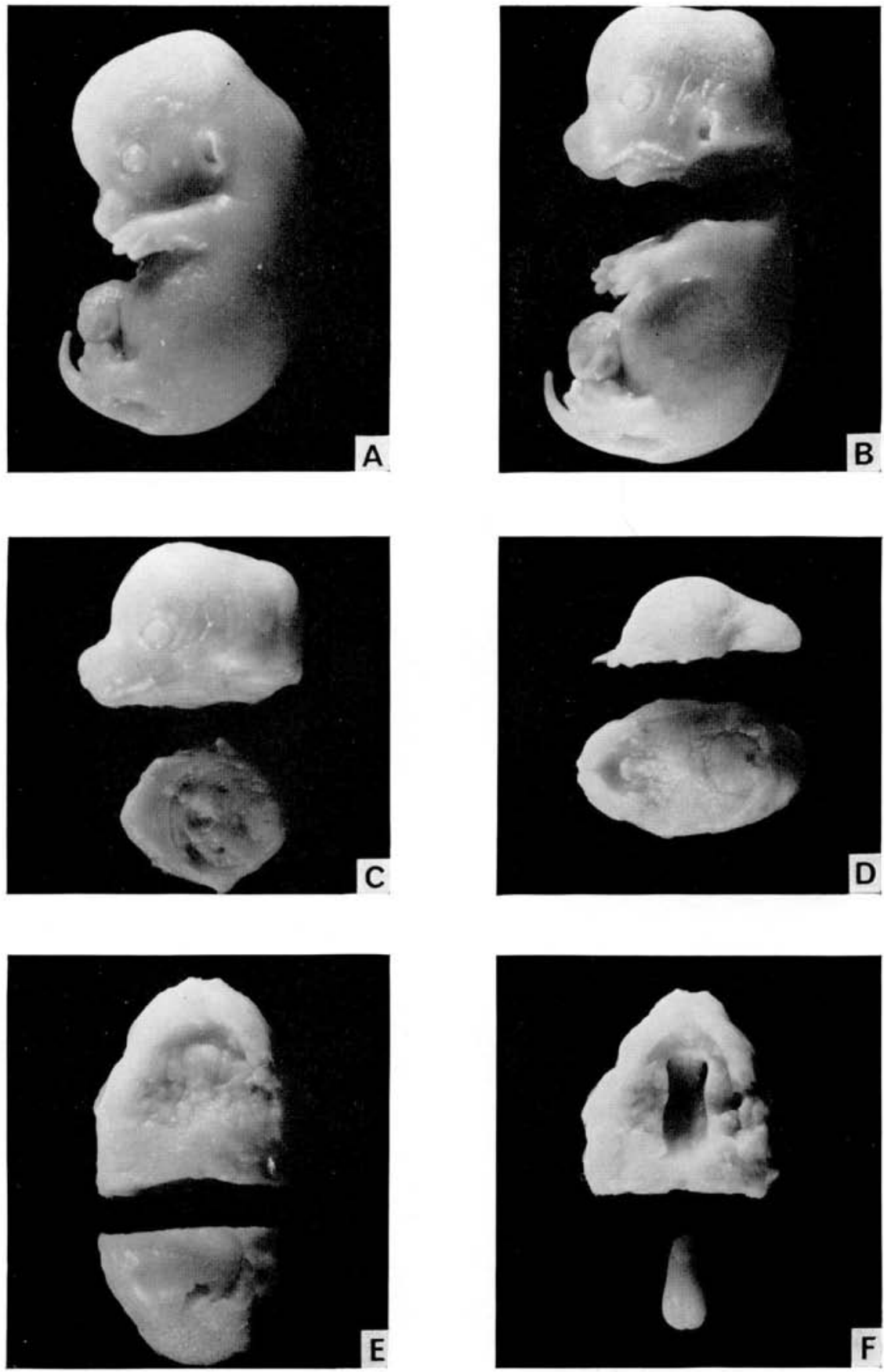

Figs. A, B, C, D $5 \mathrm{~mm}$.

Figs. $E, F$ $5 \mathrm{~mm}$. 

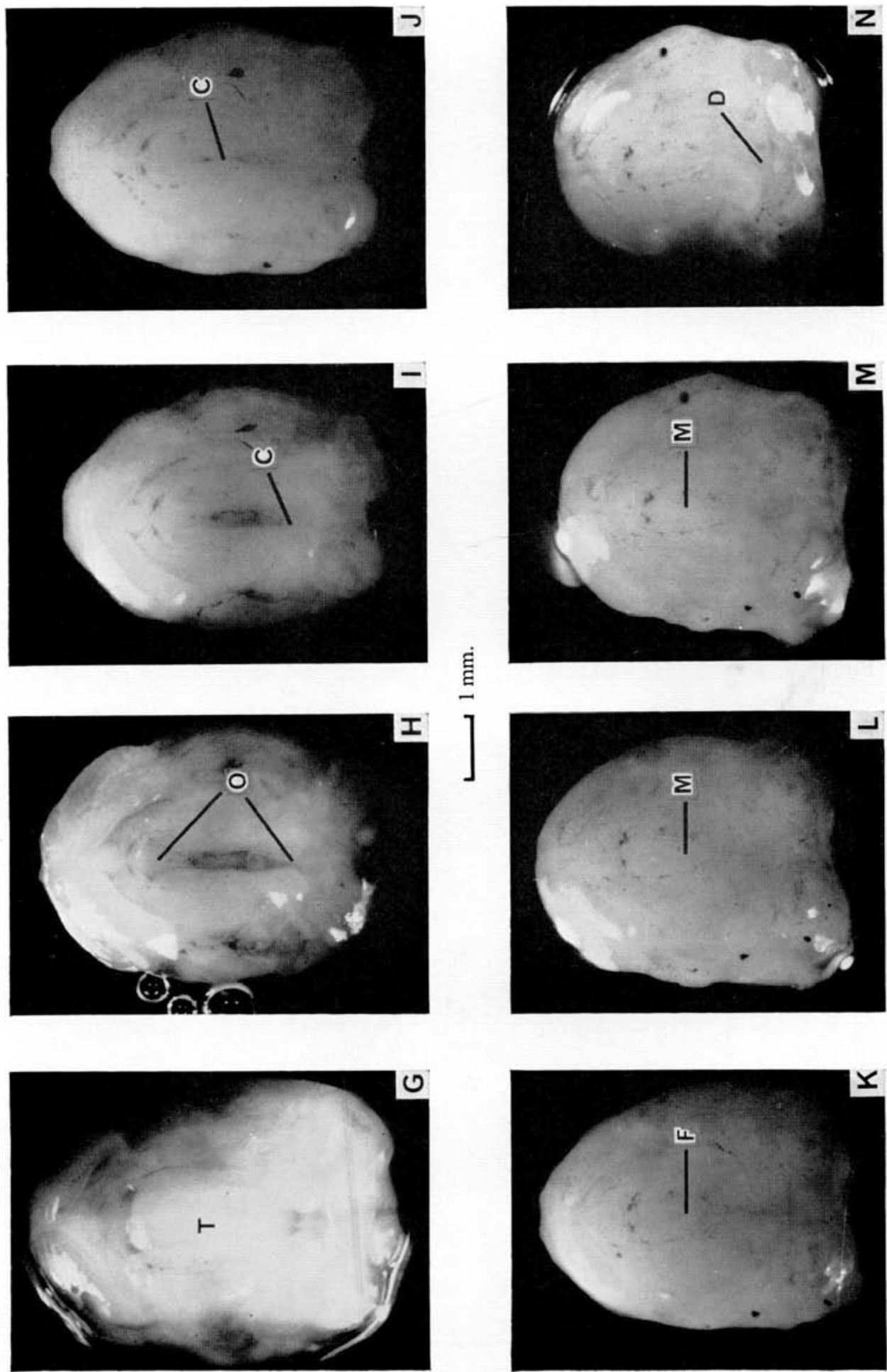

Plate 2 
removing the uterus, all of the embryos were removed, freed of their membranes and placed in a covered 90 by $15 \mathrm{~mm}$. Petri dish containing Earle's balanced salt solution.

An operating blade prepared by breaking double-edged razor blades in two was found to be most effective in cutting the embryonic tissues. One end of each blade was pointed by breaking at an acute angle. The blades were cleaned in acetone and dry heat sterilized. The embryonic tissues were excised by a steady sweeping stroke of the blade. During the operation the embryonic tissues were supported upon a 4 by 4 in. gauze pad moistened with Earle's balanced salt solution. Operations upon the embryos were done with the aid of a stereoscopic microscope.

The head of the embryo was resected at the junction of the mandible with the neck by an excision following the transverse plane of the head (Plate 1, Fig. B). The mandible was then removed (Plate 1, Fig. C). The mandible and attached tissues were discarded. In most instances, the tongue of 15-day plus 14 to $21 \mathrm{hr}$. embryo remained between the palatal processes when the mandible was excised. The tongue was not removed from between the processes until the operation was completed as it helped maintain tissue form and rigidity. The maxillary vault was then resected, starting with the operating blade upon the snout of the embryo at a point about $1.5 \mathrm{~mm}$. superior to the oral surface of the premaxilla (Plate 1, Fig. D). The excised maxillary vault was supported upon the flat surface of the operating blade and the tissues distal to the palatal processes were removed with a second operating blade (Plate 1, Fig. E).

The final tissue section used for the experiments was the middle one-third of the embryonic face including the maxillary vault. The tissue sections were approximately $4.5 \mathrm{~mm}$. in anterior-posterior length, $4 \mathrm{~mm}$. in width and 1.5 $\mathrm{mm}$. in depth. The tissues were continuous from each lateral surface of the face

\section{Plate 2}

\section{Development in vitro of a representative embryonic palatal tissue}

Fig. G. Tissue following the operation before the tongue was removed from between the processes. ' $\mathrm{T}$ ' denotes the tongue.

Fig. H. Tissue at onset of culturing. The tongue has now been removed and lines ' $O$ ' denote the ends of the open area of the palate.

Fig. I. Tissue following $12 \mathrm{hr}$. in vitro. Line ' $\mathrm{C}$ ' denotes area of contact of the processes at their distal margin.

FIG. J. Tissue following $24 \mathrm{hr}$. in vitro. Line ' $\mathrm{C}$ ' denotes the mid-line area of contact of the processes.

FIG. K. Tissue following $36 \mathrm{hr}$. in vitro. Line ' $\mathrm{F}$ ' denotes area of probable initial fusion.

FIG. L. Tissue following $48 \mathrm{hr}$. in vitro. Line ' $\mathrm{M}$ ' denotes midline location of now joined processes.

FIG. M. Tissue following $60 \mathrm{hr}$. in vitro. Line ' $\mathrm{M}$ ' denotes midline location of joined processes.

FIG. N. Tissue following $72 \mathrm{hr}$. in vitro. Line ' $\mathrm{D}$ ' denotes the distal margin of the fused processes. 
and ran anteriorly-posteriorly from the snout to just posterior to the palatal processes. This tissue section included the pre-maxilla, the maxillary ridges, the palatal processes and some of the nasal septum (Plate 1, Fig. F).

Only tissue sections which were not torn or crushed during the operating procedure were used. After completion of the operation the tissue was washed with Earle's balanced salt solution and immediately placed upon a culture clot or transplanted.

\section{Organ culture techniques}

Clots composed of equal parts of $9 \frac{1}{2}$ day-old chick embryonic extract and chicken plasma were employed. Earle's balanced salt solution was used in the preparation of the embryo extract and as a physiological rinse for the tissue during the operation.

The organ cultures were conducted in a manner similar to that described by Fell \& Robison (1929). The container consisted of a standard 100 by $15 \mathrm{~mm}$. Petri dish inverted over a 90 by $15 \mathrm{~mm}$. Petri dish. Contained within the chamber was a $65 \mathrm{~mm}$. diameter watch glass. The watch glass was supported by three small corks glued to black mat paper which was formed to fit the bottom half of the Petri dish. The watch glasses were ground to a satin finish with 000 carborundum paste. This finish eliminated reflections and transmitted a black background to the organ culture and thus improved photographic detail.

The tissues were placed with their cut or cranial surface next to the clot with the oral surface and palatal processes facing upward. The tissues were incubated at $35 \pm 0 \cdot 5^{\circ} \mathrm{C}$. At intervals of $12 \mathrm{hr}$. the palate was removed from the clot with a microspatula, washed with embryonic extract, replaced upon a new area of the clot and photographed. At the termination of the culture period the palate was removed from the clot, washed in physiological saline solution and fixed in Bouin's solution.

\section{Transplantation technique}

The transparent chamber technique employed was a modification of that of Conway et al. (1957). The inside chamber size was increased to $1.5 \mathrm{~mm}$. depth and $10 \mathrm{~mm}$. diameter, thus avoiding pressure upon the palates. The entire chamber and backing was made from cellulose acetate.

Adult $\mathrm{C} 3 \mathrm{H} / \mathrm{Jax}$ mice weighing from 25 to $30 \mathrm{~g}$. were used for the hosts in the heterograft experiments. Young Holtzman rats weighing from 70 to $95 \mathrm{~g}$. were used as hosts in the homograft experiments. The embryonic palates were placed upon a vascular bed of approximately $5 \mathrm{~mm}$. diameter prepared upon the back skin fold of the host animals. The palates were placed with their cut or cranial surface next to the vascular bed. The oral surface and palatal processes were then covered by the chamber. 
J. Embryol. exp. Morph.

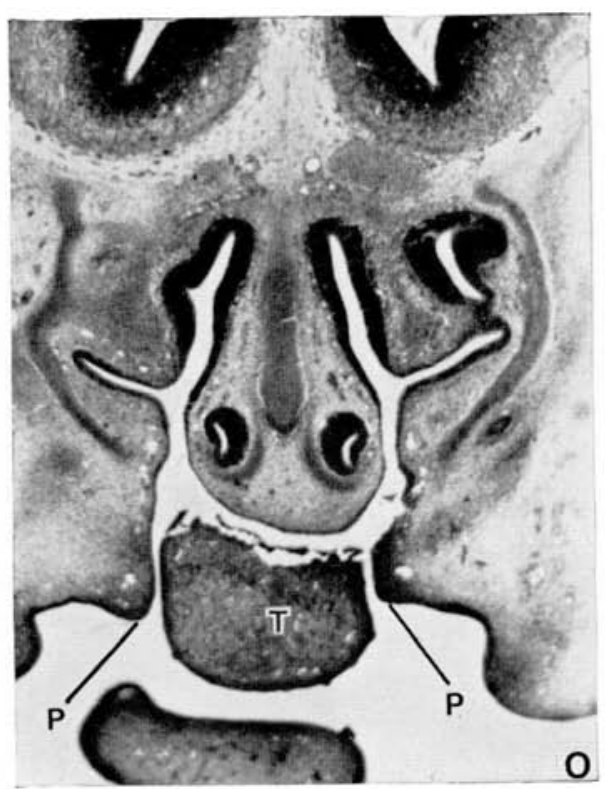

Vol. 11, Part 3

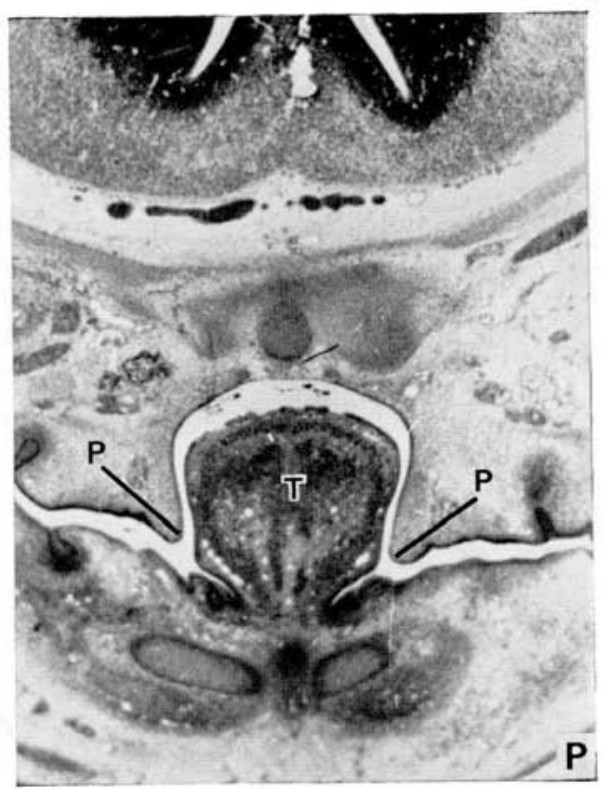

$0.5 \mathrm{~mm}$.
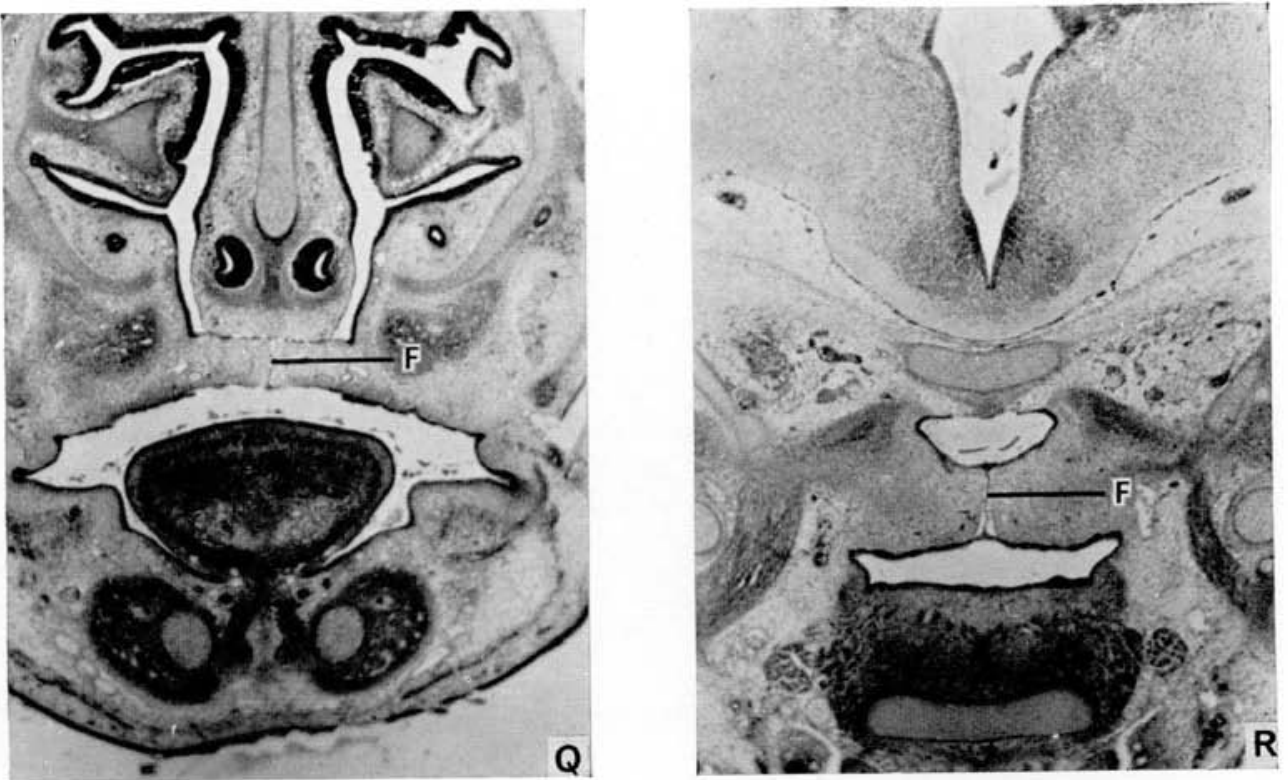

Plate 3 

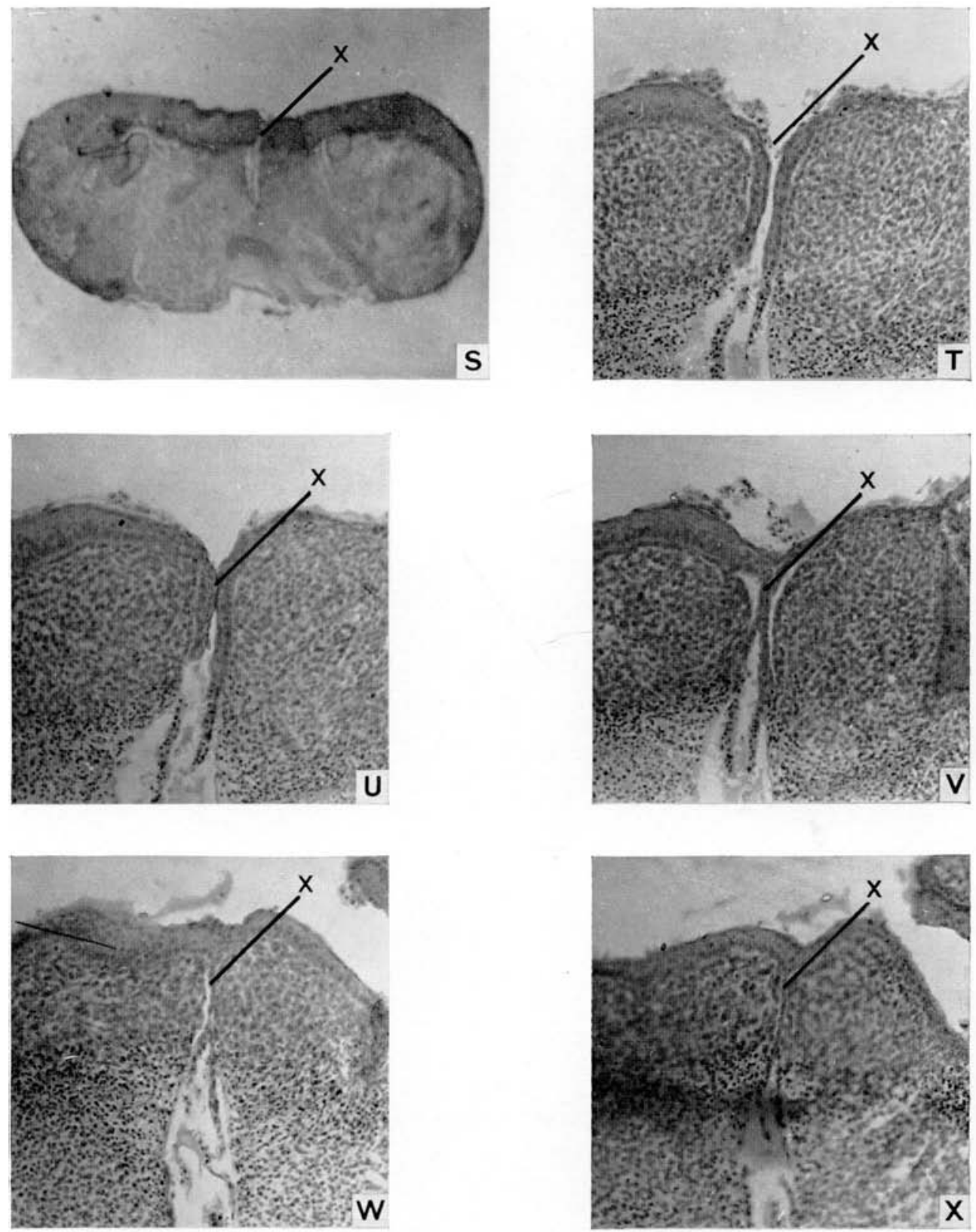

Fig. $\mathrm{S}$

$1 \mathrm{~mm}$.

Figs. $T, U, V, W, X$ $0.2 \mathrm{~mm}$

Plate 4

Frontal plane sections of an embryonic tissue which developed fusion in vitro (R40-C2). The sections start at the distal margin of the processes and progress anterior in Figs. T to X. The oral surface of the processes is superior. The lines marked ' $X$ ' denote the mid-line area of approximation and fusion of the two lateral palatal processes.

FIG. S. The entire tissue.

FIG. T. Non-contacting processes.

FIG. U. Contacting process epithelium. Epithelial fusion does not appear to have occurred.

FIG. V. Fused processes with a double epithelial cell strand remnant.

Fig. W. Fused processes with single epithelial cell strand remnant.

FIG. X. Fused processes with a broken single epithelial cell strand remnant. 
Observations and photographs were made at $12 \mathrm{hr}$. intervals. Upon termination of the experiment the chamber was removed and the palate carefully dissected from the graft site. The palate was washed with physiological saline solution and fixed in Bouin's solution.

\section{Histology}

At the termination of the in vitro and in vivo experiments the tissues were placed in Bouin's solution and fixed for $24 \mathrm{hr}$. They were then transferred to 70 per cent. ethyl alcohol, cleared, and imbedded in paraffin blocks. Serial sections of $10 \mu$ were cut on the frontal plane. A few sections of each specimen were cut at $4 \mu$. Serial sections were made of each specimen throughout the anterior-posterior length of its processes. The sections were stained with hematoxylin-eosin. Each specimen was examined for cellular and morphological characteristics and evidence of process fusion.

Histological sections of whole heads of two normal rat embryos were also prepared. One embryo had a chronological age of 15 days $18 \mathrm{hr}$. The palatal processes of this embryo were still displaced by the tongue. The other embryo had a chronological age of 16 days $16 \mathrm{hr}$. This embryo exhibited fusion of the two palatal processes. Serial frontal plane sections through the entire heads were cut at $10 \mu$ and stained with hematoxylin-eosin. These sections were used to examine normal cellular and morphological characteristics of the embryonic rat secondary palate before and after process movement and fusion. They served also as a control to evaluate changes occurring in the cellular and morphological characteristics of the tissues during the in vitro and in vivo experiments.

\section{RESULTS AND DISCUSSION}

\section{Organ culture}

A total of nineteen embryonic rat palate organ cultures were prepared. The tissues used in these experiments were obtained from embryos of six female rats.

Plate 3

\section{Histological sections of the normal developed embryos}

FIG. O. Frontal plane section of a 15-day 18-hr. embryo near the anterior end of the processes. The processes are displaced laterally by the tongue ' $T$ '. Lines ' $P$ ' denote the medial border of the processes.

FIG. P. Frontal plane section near the posterior end of the processes of same 15-day embryo as in Fig. $O$. The processes in this area are also displaced by the tongue ' $T$ '. Lines ' $P$ ' denote the medial border of the processes.

FIG. Q. Frontal plane section of a 16-day 16-hr. embryo near the anterior end of the processes. Line ' $F$ ' denotes the mid-line area of fusion of the palatine processes.

FIG. R. Frontal plane section of the same 16-day embryo near the posterior end of the processes. Line ' $F$ ' denotes the mid-line area of fusion of the palatine processes where some epithelial remnants can be noted. 
610 THOMAS M. MORIARTY, SAM WEINSTEIN AND R. D. GIBSON

The chronological ages of the embryos ranged from 15 days $14 \mathrm{hr}$. to 15 days $20 \mathrm{hr}$.

From Table 1 it can be seen that the palatal tissues were maintained in vitro for periods varying from $12 \mathrm{hr}$. to $76 \mathrm{hr}$. The $12-\mathrm{hr}$. and the 20-hr. culture lost their integrity and exhibited wandering or 'unorganized' growth. Of the remaining seventeen palates nine showed palatal process movement toward the mid-line and approximation of the medial edges of the lateral palatal processes and histological examination of these tissues revealed that five had fused. Seven exhibited medial process movement but the palatal processes did not achieve actual contact in the mid-line. One culture failed to show any appreciable movement of the palatal processes.

\section{TABLE 1}

In vitro Data

\begin{tabular}{|c|c|c|c|}
\hline $\begin{array}{c}\text { Embryo } \\
\text { code }\end{array}$ & $\begin{array}{c}\text { Chron. } \\
\text { age in } \\
\text { days/hours }\end{array}$ & $\begin{array}{c}\text { Duration } \\
\text { in } \\
\text { hours }\end{array}$ & Development during experiment \\
\hline $\mathrm{R} 3-\mathrm{C} 1$ & $15 / 14$ & 12 & Tissue became unorganized \\
\hline R3-C2 & $15 / 14$ & 48 & Processes did not meet \\
\hline R9-C1 & $15 / 20$ & 20 & Tissue became unorganized \\
\hline $\mathrm{R} 9-\mathrm{C} 2$ & $15 / 20$ & 72 & Processes did not meet \\
\hline R9-C3 & $15 / 20$ & 72 & Processes did not show any appreciable medial movement \\
\hline $\mathrm{R} 33-\mathrm{C} 1$ & $15 / 18$ & 76 & Process contact without epithelial union \\
\hline $\mathrm{R} 33-\mathrm{C} 2$ & $15 / 18$ & 76 & Processes did not meet \\
\hline R33-C3 & $15 / 18$ & 76 & Process contact without epithelial union \\
\hline $\mathrm{R} 38-\mathrm{C} 1$ & $15 / 18$ & 45 & Processes did not meet \\
\hline $\mathrm{R} 38-\mathrm{C} 2$ & $15 / 18$ & 45 & Fusion with double cell strand epithelial remnants \\
\hline R38-C3 & $15 / 18$ & 45 & Processes did not meet \\
\hline R40-C1 & $15 / 17$ & 68 & Processes did not meet \\
\hline $\mathrm{R} 40-\mathrm{C} 2$ & $15 / 17$ & 68 & Fusion with single cell strand epithelial remnants \\
\hline $\mathrm{R} 40-\mathrm{C} 3$ & $15 / 17$ & 68 & Process contact without epithelial union \\
\hline $\mathrm{R} 44-\mathrm{C} 1$ & $15 / 20$ & 72 & Fusion with isolated epithelial cells remaining \\
\hline $\mathrm{R} 44-\mathrm{C} 2$ & $15 / 20$ & 72 & Fusion with complete mesenchymal penetration \\
\hline R44-C3 & $15 / 20$ & 72 & Processes did not meet \\
\hline R44-C4 & $15 / 20$ & 72 & Process contact without epithelial union \\
\hline R44-C5 & $15 / 20$ & 72 & Fusion with complete mesenchymal penetration \\
\hline
\end{tabular}

Chronological age of the embryo and duration of development in vitro were similar for the terminal fused, for the approximated but non-fused, and for the non-approximated palatal process tissues and do not appear to have any bearing upon the end results in this study.

\section{Transplantation}

Twenty embryonic rat palates were used for the heterograft and homograft experiments. The embryonic palates were obtained from embryos of five female rats. The chronological ages of the embryos ranged from 15 days $15 \mathrm{hr}$. to 15 days $21 \mathrm{hr}$. (Table 2). 
Fifteen embryonic rat palates were heterografted to adult male and female $\mathrm{C} 3 \mathrm{H} / \mathrm{Jax}$ mice. Ten of these heterografts exhibited movement of the lateral palatal processes towards the mid-line, approximation of the medial edges of the lateral palatal processes and fusion.

Of the five heterografts whose lateral palatal processes did not fuse, four exhibited palatal process movement toward the mid-line and one of these four heterografts developed palatal process contact without cellular fusion. The other three heterografts exhibiting palatal process movement developed blood clots between the two lateral palatal processes before contact occurred. The one

\section{TABLE 2}

\section{Transplantation Data}

\begin{tabular}{cclcl} 
Embryo & $\begin{array}{c}\text { Chron. } \\
\text { code }\end{array}$ & \multicolumn{3}{c}{$\begin{array}{c}\text { Dura- } \\
\text { tion }\end{array}$} \\
age in & Host-Sex & $\begin{array}{c}\text { in } \\
\text { days/hours }\end{array}$ & \multicolumn{1}{c}{ Development during experiment } \\
R40-M1 & $15 / 17$ & C3H/Jax-M & 68 & Fusion with single cell strand epithelial remnants \\
R40-M2 & $15 / 17$ & C3H/Jax-M & 68 & Fusion with complete mesenchymal penetration \\
R40-M3 & $15 / 17$ & C3H/Jax-M & 68 & Fusion with complete mesenchymal penetration \\
R32-M1 & $15 / 15$ & C3H/Jax-F & 48 & Fusion with double cell strand epithelial remnants \\
R32-M2 & $15 / 15$ & C3H/Jax-F & 56 & Processes did not meet \\
R32-M3 & $15 / 15$ & C3H/Jax-M & 68 & Process contact without epithelial union \\
R32-M4 & $15 / 15$ & C3H/Jax-M & 76 & Fusion with single cell strand epithelial remnants \\
R36-M1 & $15 / 20$ & C3H/Jax-M & 68 & Processes did not meet \\
R36-M2 & $15 / 20$ & C3H/Jax-M & 68 & Fusion with single cell strand epithelial remnants \\
R36-M3 & $15 / 20$ & C3H/Jax-M & 68 & Processes did not meet \\
R36-M4 & $15 / 20$ & C3H/Jax-M & 68 & Fusion with double cell strand epithelial remnants \\
R34-M1 & $15 / 21$ & C3H/Jax-M & 70 & Fusion with double cell strand epithelial remnants \\
R34-M2 & $15 / 21$ & C3H/Jax-M & 70 & Fusion with double cell strand epithelial remnants \\
R34-M3 & $15 / 21$ & C3H/Jax-M & 70 & Processes did not meet \\
R34-M4 & $15 / 21$ & C3H/Jax-M & 48 & Fusion with double cell strand epithelial remnants \\
R44-R1 & $15 / 20$ & Holtzman-F & 48 & Fusion with double cell strand epithelial remnants \\
R44-R2 & $15 / 20$ & Holtzman-F & 86 & Fusion with double cell strand epithelial remnants \\
R44-R3 & $15 / 20$ & Holtzman-M & 68 & Processes did not meet \\
R44-R4 & $15 / 20$ & Holtzman-F & 68 & Fusion with double cell strand epithelial remnants \\
R44-R5 & $15 / 20$ & Holtzman-M & 48 & Fusion with single cell strand epithelial remnants
\end{tabular}

heterograft which did not exhibit an appreciable medial movement of the palatal processes developed a blood clot soon after transplantation.

The blood clots appeared to arise from excessive blood seepage from the host's vascular bed. Movement of the palatal processes seemed to cease when the blood clots formed.

Five embryonic palates were placed as homografts on young male and female Holtzman rats. Four of these five embryonic palates homografted exhibited palatal process movement towards the mid-line, approximation of the medial edges of the palatal processes and fusion. The one homograft palate which did not progress to fusion developed a blood clot between the two palatal processes 
before they came in contact. The original chronological age of the embryos used in the homograft experiments was 15 days $20 \mathrm{hr}$. These tissues were maintained in vivo for from 48 to $86 \mathrm{hr}$.

Chronological age of the embryo, sex of host animals, occurrence of vascularization and duration of the experiments were similar for both the terminal unfused and fused palates in both the homograft and heterograft experiments and do not appear to have any bearing upon the end result. Mechanical interference with process movement and contact appears to be a factor in the prevention of fusion in vivo. None of the four palatal transplants in which blood clots formed between the lateral palatal processes developed fusion. In several instances momentary separation of touching palatal processes was observed when the skin flap of the host animal moved.

Some edema of the host tissues in the area of the transparent chamber was always present. In several of the grafts sufficient swelling occurred to press the transplanted palatal tissues against the chamber window thus disturbing process movement.

It was not possible to determine by direct observations when fusion occurred during the experiments. The transplants were removed at predetermined times or when conditions adverse to the experiment developed. All the transplanted palatal tissues appeared slightly edematous when removed. Usually a very firm vascular attachment was present between the prepared vascular bed and the transplanted palatal tissue.

Morphology of closure and fusion of the palatal processes in vitro and in vivo.

The technique employed in this research afforded the opportunity to observe directly the closure and fusion of the lateral palatal processes of the rat embryo. The in vitro and in vivo experiments isolate the palatal processes from the possible influences of adjacent structures and the technique employed necessitated the removal of the tongue from between the processes at an earlier time than occurs in normal development. Sicher (1961) and Orban (1953) believed that the normal morphology of closure is an interrelation of all the tissues involved. Isolation of the palatal processes from some of the adjacent tissues, the early removal of the tongue from between the processes and the transfer of the palatal tissues to a foreign environment may effect a different mode of closure in culture and in grafts from the normal.

The morphology of palatal closure in embryos of the Sprague-Dawley rat has been described by Zeiler (1961). He noted that tongue position, morphology and development affected the position and morphology of the palatal processes. While the tongue was interposed between the palatal processes it had a definite molding effect upon them. Prior to closure the anterior halves of the two processes were directed ventro-medially along the inferio-lateral margins of the tongue while the posterior ends of the processes were oriented vertically along 
its lateral margins. The open area between the processes thus had an hour-glass form. As the developing tongue and processes increased in size, the processes moved from a caudal to a cranial position, in relation to the tongue, in their anterior half, and assumed a horizontal position. Medial contact of the two processes developed near the anterior end of the open palate while the posterior ends of the processes were still displaced laterally and vertically by the tongue. Fusion of the two processes began along the mid-line after contact had developed and the open area of the palate was then divided into an anterior and a posterior area. Fusion progressed along the median line both anteriorly and posteriorly over one-half of the original open area before the processes completely assumed a horizontal position along their entire length. During the medial fusion of the two processes the pre-maxilla grew posteriorly to meet and fuse with the anterior ends of the processes. The final form of the maxillary vault was concave in the transverse and sagittal planes of the oral surface.

The palatal tissues grown in vitro, in most instances, retained their external morphological characteristics to a remarkable degree. Oral view photographs showing the development, closure and fusion of a representative cultured embryonic palate are shown in Plate 2. The photographs were taken at $12 \mathrm{hr}$.intervals.

The palatal tissue following the completion of the operation is shown in Plate 2, Fig. G. The tongue is interposed between the processes and fills the open area of the palate except for the two small anterio-lateral boundaries at the rostral end of the opening and a rectangular opening at the posterior end of the palate. The anterior halves of the palatal processes are deflected vertically by the tongue and converge toward their posterior end to lie nearly horizontal over the caudal surface of the posterior end of the tongue. This distal opening of the palate is bounded by the tongue along the anterior margin, the two palatal processes on the lateral boundaries and the posterior wall of the pharynx on its posterior margin.

The appearance of this tissue following the removal of the tongue is shown in Plate 2, Fig. H. The palatal processes are now horizontal along their entire length. The nasal septum can be seen to arise from the posterior boundary of the pre-maxilla and extend distally through the anterior third of the open palate. The palatal processes, starting from their anterio-lateral boundaries, converge slightly medially over the anterior third of the palate, open slightly over the middle third and then converge to almost contact at their distal boundary. The open area of the palate has an hour-glass form similar to that described by Zeiler (1961) but the palatal processes are entirely horizontal rather than rotated from an anterior vertical to a posterior horizontal position.

In most cases the tongue was held rather firmly between the two palatal processes. When the tongue was removed the processes assumed a horizontal position immediately. This is similar to the observations upon mice embryos by Walker \&.Fraser (1956) but did not appear to be a forceful movement of the processes. 
614 THOMAS M. MORIARTY, SAM WEINSTEIN AND R. D. GIBSON

The initial contact of the cultured palatal processes was at their posterior end. This differs from Zeiler's (1961) findings as he noted initial contact by the anterior third of the processes while their posterior third was still displaced laterally and vertically by the tongue. The medial margins of the palatal process after $12 \mathrm{hr}$. in vitro are nearly parallel through the middle half of the open area while a slight divergence is present in the anterior end of the open palate over the nasal septum. The nasal septum has continued to extend more distally between the processes (Plate 2, Fig. I).

Closure of the palatal processes in vitro is nearly complete after $24 \mathrm{hr}$. The opening has been reduced to a fine Y-shaped formation open slightly in its middle half. Closure has been by a parallel union of the processes throughout most of their length. This is similar to the parallel closure of normal mouse palates described by Walker \& Fraser (1956). This parallel closure is demonstrated in Plate 2, Figs. I and J.

Actual fusion of the processes was difficult to determine during the experiments even under microscopic observation of the live tissues. No attempts were made to test adherence of the two processes as it was feared the tissues might become torn. Fusion was considered to have occurred when no definite demarcation between the two processes could be seen. Fusion appeared to begin first in the anterior third of the opening just distal of the V-form between the two processes and the nasal septum. Initial fusion divided the previous $\mathrm{Y}$-shaped opening into an anterior V-form and a distal median straight line opening (Plate 2, Fig. K). Fusion appeared to progress distally between the two contacting processes and anteriorly into the V-form to join the two palatal processes with the pre-maxilla (Plate 2, Fig. L). After 48 hours in vitro fusion of the two palatal processes was nearly complete throughout the original opening with the exception of the posterior end. The fusion has progressed slightly more distally at $60 \mathrm{hr}$. and appears complete at $72 \mathrm{hr}$. in vitro (Plate 2, Figs, L, M and N).

During in vitro development the palatal tissues exhibited a slight decrease in size rather than an increase in area. After about $60 \mathrm{hr}$. the explants usually became cloudy in appearance. Several of them developed a wavy mid-line union of the palatal processes and in some cases the median line of union curved at its distal border toward one side.

The transplanted embryonic palates showed the same form of closure and fusion as the cultured ones. The processes assumed a horizontal position immediately following removal of the tongue and initial contact was made at their posterior borders. The open area of the palate was also in the form of an hour-glass initially and the processes closed along parallel lines to form a $Y$-shaped contact area. The initial area of fusion also appeared to occur in the anterior third at the base of the anterior V-form.

The transplanted tissues became slightly edematous but maintained their original size and morphological characteristics during the experiments. Details 
of closure and fusion were more difficult to observe during the transplantation experiments.

Differences between experimental and normal development can possibly be attributed to the lack of the interaction of adjacent tissues, such as the tongue, and also to the change in the environment. The lack of the tongue appears to alter the morphology and the site of initial contact of the palatal processes. The initial site of fusion (the base of the V-form where the first anterior contact of the processes occurs) appears to be the same in both experimental and normal development. The oral surface of the experimental tissues was slightly convex in the transverse plane and straight in the sagittal plane rather than concave as the normal palatal form. This could be attributed to a lack of molding influences from the tongue and/or a factor of environmental change.

\section{Histology of the normal palatal processes}

The two embryo heads selected for histological examination are representative of palatal development at the beginning of process movement and at the termination of complete medial contact with early fusion. The sections of the 15-day 18-hr. embryo head were used as a representative basis for the histology of the tissues prior to experimentation. The sections of the head of the 16-day 16-hr. embryo were used as a basis for development achieved by normal embryos to the point of complete palatal process contact with early fusion.

Frontal plane sections from the 15-day embryo show the lateral palatal processes to be displaced laterally and caudally by the tongue throughout their entire anterior-posterior length (Plate 3, Figs. $\mathrm{O}$ and $\mathrm{P}$ ). These palatal processes are composed of mesenchymal cells with an epithelial covering. The epithelial covering is continuous with the epithelia of the nasal and oral chambers and is composed of cuboidal cells. Along the nasal surface of the processes the epithelium is made up of a single layer of cells. This single layer of epithelium changes to a double cell layer along the oral surface of the processes and builds up to three and four cell layers where the palatal processes join the maxillary processes.

The mesenchyme of the processes is composed mostly of loose, undifferentiated, stellate cells. The mesenchymal cells are condensed in two areas. One area of condensation is located at the medial edges, while the other area of condensation is located at the bases of the processes. The mesenchymal cells in the areas of condensation are much less stellate and more closely arranged.

The frontal plane sections from the head of the 16-day embryo showed the palatal processes to be meeting along the mid-line throughout their entire anterior-posterior length (Plate 3, Figs. Q and R). Fusion with varying degrees of epithelial cell remnants between the two processes is present throughout the anterior-posterior dimension of the medial contact area.

The mesenchymal tissue of the now joined processes is composed chiefly of loosely arranged, stellate, undifferentiated mesenchymal cells. The mesenchyme appears to be generally more loosely arranged than that of the 15-day 
616 THOMAS M. MORIARTY, SAM WEINSTEIN AND R. D. GIBSON embryo and there is an even distribution of mitotic figures among the cells of the palatal tissues. The mesenchymal condensation which was previously present at the medial edges of the processes has disappeared. However, the lateral boundaries of the palatal vault still shows some mesenchymal condensations.

The area of palatal process contact and fusion is still noticeable as remnants of the original epithelial coverings are still found throughout the anteriorposterior length of the palatal mid-line. The epithelial remnants are not consistent in character, sometimes remaining as double cell strands, single cell strands, isolated groups of cells and and are even completely absent in some of the sections.

\section{Histology of the experimental tissues}

Neither the in vitro and in vivo environments provided optimal conditions for further development of the embryonic palatal tissues. The foreign environment, the disruption of normal embryonic relationships by the operations upon the embryo and its tissues and the trauma of the operation itself caused some changes in the morphology and histology of the tissues (Latta, 1961). All the experimental tissues underwent histological 'depression' or incipient degenerations and organotypical growth was changed or distorted to some degree. Even with the above-mentioned changes a number of the experimental palates did develop process contact and fusion.

Gross examinations of the tissues during experimentation and further histological studies revealed certain general changes. In all cases the size of the tissues at termination of the experiment was less than in normal development. The morphology of the experimental tissues remained but failed to develop or maintain fine details as do normal tissues. The palatal vault area of these tissues become flat or convex on their oral surfaces rather than concave and the nasal chambers collapsed or became compressed.

The cells of the experimental tissues underwent certain changes such as shortening of the stellate processes of the mesenchymal cells, cornification of the epithelial cells and other 'depression' processes.

\section{Histology of fusion obtained in the experimental tissues}

Five of the cultured tissues and fourteen of the transplanted tissues showed fusion, which resembled normal palatal process fusion.

The degrees of fusion obtained in the experimental tissues varied both within an individual palate and between different ones. The degrees of fusion ranged from early fusion by epithelial elements (double cell strands of epithelial elements remaining in the line of fusion) to loss of all epithelial elements and complete mesenchymal penetration. In some cases the epithelial remnants consisted of single cell epithelial strands and in a few cases epithelial pearls were present in the line of fusion. 
Descriptions of the highest degree of fusion obtained in each of the explants are found in Table 1. The degree of fusion obtained in each transplant are found in Table 2.

Both the cultured and the transplanted palates which developed fusion presented a marked degeneration of the epithelial lining of the enclosed nasal chamber. This epithelial lining was often broken, lacked the basement membrane and usually was separated from the wall of the nasal chamber.

The sections of one explant (R40-C2) show a wide variety of fusion progress. Development was apparently stopped in this specimen as contact and fusion were nearing the distal ends of the palatal processes. Serial sections of this tissue show progressive development of contact and fusion as the sections progress from the distal ends of the processes to their middle third. The most distal sections show lack of contact among the processes. More anterior sections show development of contact and fusion between the two processes. The epithelial fusion begins as a double cell bar of cuboidal epithelium. As the sections progress anteriorly the epithelial structure changes to a strand of single cell remnants. Photomicrographs of this tissue are shown on Plate 4.

The changing degree of fusion in this tissue closely resembles the process of fusion as described by Barry (1961).

The degree of epithelial fusion and mesenchymal penetration in both the normal and experimental palates does not appear to be developing to the same degree along the entire length of the processes' medial contact. It appears that varying degrees of epithelial structures and mesenchymal penetrations are found throughout the area of fusion in individual specimens of both the normal and the experimental tissues.

\section{SUMMARY}

1. The feasibility of employing organ culture and transplantation techniques for obtaining fusion of the lateral palatal processes of the rat embryo was investigated. The methods of obtaining live embryos and the operations upon these embryos to obtain palatal tissues were described.

2. Nineteen organ cultures of the unfused palatal tissues of 15-day SpragueDawley rat embryos were made. Five of these palates achieved fusion. Twenty transplantations of the unfused palatal tissues of 15-day Sprague-Dawley rat embryos were carried out. Ten of the heterografted palates developed fusion. Four of the five homografts achieved fusion.

3. The morphology of palatal process closure was observed and photographed at regular intervals in the in vitro and in vivo experiments. The morphology of closure of the secondary palate as found in the experimental tissues differs slightly from that of normal Sprague-Dawley embryos.

4. The tongue appears to have a direct relationship with morphology and mode of closure. Removal of the tongue from between the lateral palatal 
processes of the experimental tissues immediately modifies process morphology and mode of closure.

5. The abnormal environments of both explants and transplants cause cellular 'regressions' in them.

6. The histological progress of cellular fusion appears similar for the experimental and normal tissues.

\section{RÉSUMÉ}

Déroulement, in vitro et in vivo, de la fusion des processus palatins de l'embryon de Rat

1. On a étudié la possibilité de l'emploi des cultures d'organes et des techniques de transplantation pour obtenir la fusion des processus palatins latéraux. On a décrit les méthodes d'obtention d'embryons vivants et les opérations réalisées sur ces embryons pour obtenir des tissus palatins.

2. Dix-neuf cultures d'organes de tissus palatins non-fusionnés, d'embryons de Rat Sprague-Dawley de 15 jours, ont été réalisées. Cinq de ces palais ont achevé leur fusion. Vingt transplantations de ces tissus palatins non fusionnés de même âge et de même origine ont été réalisées. Dix des hétérogreffes palatines ont fusionné. Quatre des cinq homogreffes ont achevé de fusionner.

3. On a observé et photographié à intervalles réguliers la morphologie de la fermeture palatine dans les expériences faites in vitro et in vivo. Telle qu'elle a été observée sur les tissus en expérience, la morphologie de la fermeture du palais secondaire diffère légèrement de celle des embryons normaux SpragueDawley.

4. La langue se révèle être en rapport direct avec la morphologie et le type de fermeture. L'ablation de la langue entre les processus palatins latéraux des tissus en expérience modifie immédiatement la morphologie des processus et le mode de fermeture.

5. Le milieu environnant, anormal, provoque des 'régressions' cellulaires, à la fois chez les explants et les transplants.

6. Les phénomènes histologiques de fusion cellulaire sont semblables chez les tissus normaux et les tissus en expérience.

\section{ACKNOWLEDGEMENT}

The authors wish to extend their sincere appreciation to Dr Edward H. Holyoke, Dr John S. Latta, Dr J. E. Shannon, Jr., Mr James R. Thompson, Dr Patrick R. Wells and Dr Karl B. Zeiler.

\section{REFERENCES}

Asling, C. W., Nelson, M. M., Dougherty, H. L., Wright, H. V. \& Evans, H. M. (1960). The development of cleft palate resulting from maternal pteroylglutamic (folic) acid deficiency during the latter half of gestation in rats. Surg. Gynec. Obstet. 111, 19-28. 
BARRY, A. (1961). Development of the branchial region of human embryos with special reference to the fate of epithelia. In Congenital Anomalies of the Face and Associated Structures (ed. S. Purzansky), pp. 46-62. Springfield: Charles C. Thomas.

Conway, H., Griffith, B. H., Shannon, J. E. \& Findley, A. (1957). Re-examination of the transparent chamber as applied to the study of circulation in autografts and homografts of the skin. Plast. reconstr. Surg. 20, 103-16.

Fell, H. B. \& Robison, R. (1929). The growth, development and phosphatase activity of embryonic avian femora and limb buds cultivated in vitro. Biochem. J. 23, 767-84.

FeLL, H. B. (1940). The application of tissue culture in vitro to embryology. J. R. micro. Soc. 60, 95-112.

Fraser, F. C., Walker, B. E. \& Trasler, D. G. (1957). Experimental production of congenital cleft palate; genetic and environmental factors. Pediatrics, 19, 782-7.

KALTER, H. \& WARKANY, J. (1959). Experimental production of congenital malformations in mammals by metabolic procedure. Physiol. Rev. 39, 69-115.

LatTa, J. S. (1961). Personal communication.

Orban, B. (1953). Oral Histology and Embryology, 3rd Ed. St. Louis: C. V. Mosby Co.

SABET, T. Y., Hidvegi, F. B. \& RAY, R. D. (1961). A chamber for in vivo observations of living organs. Plast. reconstr. Surg. 27, 105-8.

Sicher, H. (1961). Personal communication.

WALKer, B. E. \& Fraser, F. C. (1956.) Closure of the secondary palate in three strains of mice. J. Embryol. exp. Morph. 4, Part 2, 176-82.

WALKER, B. E. (1961). The association of mucopolysaccharides with morphogenesis of the palate and other structures in mouse embryos. J. Embryol. exp. Morph. 9, Part 1, 22-31.

ZEILER, K. B. (1961). A study of the morphology and the time of closure of the palate in the albino rat. Unpublished Master's Thesis, University of Nebraska.

(Manuscript received 4th March 1963) 